\title{
Five new species of soil burrowing cockroaches from Queensland (Blattodea: Blaberidae: Geoscapheinae)
}

\author{
H.A. ROSE \\ Faculty of Agriculture and Environment, University of Sydney, NSW 2006. Corresponding author: \\ harley.rose@sydney.edu.au
}

\section{J.A. WALKER}

Commonwealth Department of Agriculture, Box 96, Cairns International Airport, Cairns, QId 4870

\section{J.R. WOODWARD}

School of Botany, University of Melbourne, Vic 3010

http://dx.doi.org/10.17082/j.2204-1478.59.2014.2014-02

LSID urn:Isid:zoobank.org:pub:F837EAC9-D3C6-42E4-84F6-3CB4B1583510 :

Citation: Rose, H.A., Walker, J.A. \& Woodward, J.R. 2014: Five new species of soil burrowing cockroaches from Queensland (Blattodea: Blaberidae: Geoscapheinae). Memoirs of the Queensland Museum - Nature 59: 11-23. Brisbane. ISSN 2204-1478 (Online), ISSN 0079-8835 (Print). Accepted: 30 October 2014. First published online: 23 December 2014.

\begin{abstract}
Five new species of soil burrowing Geoscapheinae are described from Queensland: Macropanesthia intermorpha, $M$. lineopunctata, $M$. mutica, $M$. spuritegmina, and Neogeoscapheus hanni. Redescriptions of subfamilies Panesthiinae and Geoscapheinae are given, and a key to the genera of Geoscapheinae and keys to species of Macropanesthia and Neogeoscapheus are provided. $\square$ Blattodea, Blaberidae, Geoscapheinae, Panesthiinae, Australian ground burrowing cockroaches
\end{abstract}

Within the cockroach family Blaberidae, the subfamily Geoscapheinae is an Australian endemic group of cockroaches living in permanent burrows in sandy or loamy soils; their diet is dry leaves. The subfamily Panesthiinae occurs in India, Tibet, China, Japan, South East Asia, the island of New Guinea, Indonesia, Australia and some Pacific islands; most feed on rotting wood and two species are known to feed on dry leaves. The two subfamilies have close genetic affinities (Maekawa et al., 2003). Morphologically, the two subfamilies are very similar and the taxonomic division is based on two characters. The first is related to the absence of wings or tegmina in Geoscapheinae, and their presence or absence in Panesthiinae. Those Panesthia lacking wings or tegmina were differentiated from Geoscapheinae using the second character which relates to the laterocaudal angle of tergite 7. Roth (1977) differentiated Australian
Panesthia from Geoscapheinae mainly on the basis of the laterocaudal angle of tergite 7: in Panesthiinae, if such a process is produced, it is directed caudally and not upwards, whereas in Geoscapheinae this process is 'directed laterally or obliquely, and slightly or strongly dorsad'. This character was no longer useful in 1994 when Walker et al. described new species of Geoscapheinae, one of which had laterocaudal angles of tergite 7 produced acutely and directed ventrocaudally.

In this paper we describe five new species of Geoscapheinae, one with processes at the laterocaudal angle of tergite 7 only very weakly produced, and we have therefore modified the descriptions of Australian Panesthiinae and Geoscapheinae to accommodate all known species. Herein are four new species of Macropanesthia from central and northern 
Queensland and one new Neogeoscapheus from northern Queensland, bringing the total number of Geoscapheinae to 24.

Keys to Macropanesthia and Neogeoscapheus from Walker et al. (1994) have been modified. These are for adult specimens only, but may also be effective when applied to some late instar nymphs.

Measurements are in millimetres and scale bars represent $5 \mathrm{~mm}$. In descriptions of males, measurements of the holotype are given and those of paratypes are in brackets. Measurements of females refer to paratypes. Numbers of paratypes measured are in brackets. Terminology used for male genital phallomeres is that of McKittrick (1964) and Roth (1977).

\section{Abbreviations Used}

Collectors. ACK, A.C. Kotze; GBM, G.B. Monteith; HAR, H.A. Rose; JAW, J.A. Walker; JRW, J.R. Woodward.

Museums and Collections. ANIC, Australian National Insect Collection, Canberra; DAFF, Queensland Department of Agriculture, Fisheries and Forestry, Brisbane; QM, Queensland Museum, Brisbane; USIC, University of Sydney Insect Collection, Sydney; JAWPC, James Walker private collection, Cairns.

\section{SYSTEMATICS}

(Blattodea: Blaberoidea, Blaberidae, Geoscapheinae, Panesthiinae)

The higher-level classification of Blattodea is undergoing re-assessment due to the assignment to this order of the termites (epifamily Termitoidae) (Inward et al., 2007; Beccaloni \& Eggleton, 2011; 2013). Within the Blaberidae there are several subfamilies one of which is Panesthiinae, the characteristics of which were described by Roth (1977). At that time members of Panesthiinae consisted of both wood feeding and soil burrowing cockroaches; however, differences between these two groups were considered by Rugg and Rose (1984) to warrant subfamily status, so Geoscapheinae was erected to accommodate the soil burrowing cockroaches. Descriptions of these two subfamilies were subsequently modified by Walker et al. (1994). We now make further modifications to the subfamily descriptions, by deleting reference to $\mathrm{T} 7$, to account for the new species described herein.

\section{Subfamily Panesthiinae}

Living in rotting logs and feeding on wood, or living under rocks and feeding on dry leaves; robust, well sclerotised and having strong tibial spines; front femora with tibial spines modified for digging; wings or tegmina usually present (though may be vestigial or reduced through damage); ocellar spots usually present; anterior pronotal tubercles usually present in males; usually with a full complement of male blaberid genital phallomeres; oothecal membrane present.

\section{Subfamily Geoscapheinae}

Living in permanent burrows in soil and feeding on dry plant material, predominantly leaves; robust, well sclerotised and having strong tibial spines; front femora with tibial spines modified for digging; apterous; ocellar spots absent; anterior pronotal tubercles present or absent; always with a loss of one, or more, male blaberid genital phallomeres; oothecal membrane present or absent.

\section{KEY TO THE GENERA OF GEOSCAPHEINAE}

1. Posterior margin of tergite 6 without spines or tubercles exclusive of the laterocaudal angle, but may be thickened and weakly undulate or with a raised ridge........ 2

- Posterior margin of tergite 6 with one or more raised spines or tubercles exclusive of the laterocaudal angle.............. 3

2. Laterocaudal angle of tergite 6 produced into a dorsally curved spine.Geoscapheus Tepper

- Laterocaudal angle of tergite 6 not produced into a large spine.. Macropanesthia Saussure

3. Posterior margin of tergite 6 thickened laterally and with several erect rounded tubercles arising from the thickened margin .................Parapanesthia Roth 
- Posterior margin of tergite 6 with one or more acute spines or broadly rounded tubercles arising sublaterally... Neogeoscapheus Roth

\section{KEY TO SPECIES OF MACROPANESTHIA}

1. Thoracic nota coloured uniformly (ferruginous, dark brown or black) .....2

- Thoracic nota with a distinct lateral marginal yellow, or cream to orange band kraussiana (Saussure)

- Mesonotum and metanotum dark brown to black and with submarginal smoky yellow to orange patches laterally ................ spuritegmina sp. nov.

2. Anterolateral corners of tergites 6 and 7 (and often 5) with deep pits.......... 3

- Anterolateral corners of tergites without such pits ..................

3. Posterior margin of supraanal plate smooth, lateral corners (posterior to cerci) rounded ............ mackerrasae Roth

- Posterior margin of supraanal plate crenulate, lateral corners (posterior to cerci) produced into acute spines .... kinkuna Walker et al.

4. Cerci apically bulbous, dorsal surface covered with short dense setae ..... 5

- Cerci subrectangular and usually concave dorsally either side of a basal medial ridge, dorsal surface glabrous or sparsely setose. . 8

5. Laterocaudal angle of tergite 7 produced into a sharp spine and directed dorsally . 6

- Laterocaudal angle of tergite 7 produced acutely and directed ventrocaudally .................. rothi Walker et al.

6. Tergites smooth or weakly and sparsely punctate ................... 7

- Tergites having a row of deep punctations on the anterior margin (Fig. 2) ............. lineopunctata sp. nov.

7. Pronotal length less than $15 \mathrm{~mm}$; total insect length less than $55 \mathrm{~mm}$; males with weakly developed pronotal-disc tubercles .............. heppleorum Walker et al.
- Pronotal length greater than $15 \mathrm{~mm}$; total insect length usually greater than $60 \mathrm{~mm}$; males with clearly developed pronotal-disc tubercles .......... rhinoceros Saussure

8. Tergite 4 strongly punctate medially ................ intermorpha sp. nov.

- Tergite 4 smooth or very finely punctate medially .................... 9

9. Lateral margin of sternite 7 projecting beyond the lateral margin of tergite 7 and visible dorsally (Fig. 5) .... mutica sp. nov.

- Lateral margin of sternite 7 not projecting beyond the lateral margin of tergite 7 and not visible dorsally .............. 10

10. Posterior margin of tergite 6 with a broadly rounded peak $3-5 \mathrm{~mm}$ from lateral margin .............. lithgowae Walker et al.

- Posterior margin of tergite 6 thickened laterally $\ldots \ldots \ldots \ldots \ldots \ldots \ldots \ldots \ldots \ldots$

11. Pronotal width less than $18 \mathrm{~mm}$; total insect length up to (but usually less than) $40 \mathrm{~mm}$; pronotum of male with weak medial posteromarginal tubercles ................. saxicola Walker et al.

- Pronotal width greater than $19 \mathrm{~mm}$; total insect length 40-60 $\mathrm{mm}$ (usually greater than $45 \mathrm{~mm}$ ); pronotum of male with strong medial posteromarginal tubercules .................monteithi Roth

\section{KEY TO SPECIES OF NEOGEOSCAPHEUS}

1. Laterocaudal angle of tergite 6 produced into a large spine directed laterodorsally; lateral margin of sternite 7 projecting beyond lateral margin of tergite 7 when viewed dorsally (Fig. 9) .... hanni sp. nov.

- Laterocaudal angle of tergite 6 not produced into a large spine; lateral margin of sternite 7 not projecting beyond lateral margin of tergite 7 when viewed dorsally. . 2

2. Posterior margin of tergite 6 with one or more large spines exclusive of the laterocaudal angle $\ldots \ldots \ldots \ldots \ldots . . .3$

- Posterior margin of tergite 6 with a sublateral rounded tubercle on each side ................... hirsutus (Shaw) 
3. Tergite 6 with laterocaudal angle produced into a small spine directed ventrocaudally, anterolateral corner with a deep pit ................... dahmsi Roth

- Tergite 6 without laterocaudal angle produced into a spine and anterolateral pit absent ............. barbarae Walker et al.

\section{Macropanesthia intermorpha sp. nov.} (Fig. 1)

Etymology. From the possession of some morphological features similar to those of $M$. rhinoceros, $M$. heppleorum and $G$. dilatatus.

Material Examined. (North Central Queensland)

Holotype. QM: ô, QMT189900, 1956'13'S 144¹6'04’E, Poison Creek, $101 \mathrm{~km}$ NNE of Hughenden, $850 \mathrm{~m}$, dug up, 19.iv.1995, HAR, JAW, JRW.

Paratypes. ANIC $1 \delta, 1+19^{\circ} 57^{\prime} \mathrm{S} 144^{\circ} 18^{\prime} \mathrm{E}$, Poison Creek via Kennedy Development Rd, $142 \mathrm{~km}$ S of The Lynd, dug up, 15.x.1994, JRW. QM: 1ठ̋', QMT189901, 19, QMT189902, same data as holotype.

Other Material. JAWPC: 18,1 , same data as holotype; 3 ㅇ, S19.9370 E144.2677\%, Poison Ck via Kennedy Development Rd, 850 m, dug up, 20.iii.2004, HAR, JAW, JRW. QM: $1 \delta^{\wedge}, 19^{\circ} 57^{\prime}$ S 144'18'E, Poison Creek, via Kennedy Development Rd, $142 \mathrm{~km}$ S of The Lynd, dug up, 15.x.1994, JRW; 1 đ nymph, 1 오 nymph, 19'57'S $144^{\circ} 18^{\prime} \mathrm{E}$, Poison Creek via Kennedy Development Rd, $142 \mathrm{~km} \mathrm{~S}$ of The Lynd, dug up, 31.iii.1997, ACK, HAR, JRW; $1 \delta, 1$, $\$$, $19.9370^{\circ} \mathrm{E} 144.2677^{\circ}$, Poison Ck via Kennedy Development Rd, 850 m, dug up, 20.iii.2004, HAR, JAW, JRW. USIC: 19 , same data as holotype; $19, \mathrm{~S}^{\circ} 9.9483^{\circ} \mathrm{E} 144.2754^{\circ}$, nr Poison Creek, $99 \mathrm{~km} \mathrm{~N}$ of Hughenden, dug up, 16.ix.2012, HAR, JRW.

\section{DESCRIPTION}

Male. Colour. Head ferruginous, genae, clypeus and labrum dark brown to black; pronotum ferruginous laterally and posteriorly, dark red brown to black medially and anteriorly; meso- and metanotum ferruginous; legs ferruginous, tibial spines black apically; tergite 1 ferruginous; T2-4 ferruginous medially, dark red brown to black laterally; T5-7 and supraanal plate dark red brown to black; sternites ferruginous medially, dark brown to black laterally; subgenital plate and cerci dark red brown; dorsal and ventral surfaces shiny.
Measurements. Total length, 54.4 (50.2 - 55.2); pronotal length $\times$ width, $14.8 \times 21.8(14.8-15.1$ $\times 22.0-22.5)(n=2)$.

Head. Hidden beneath pronotum, finely punctate, frons slightly wrinkled.

Thorax. Pronotum densely and weakly punctate laterally, finely punctate posteriorly, anterior margin thickened and raised, disc anteriorly weakly striate and granulose, depressed medially with two oblique anterior grooves; meso- and metanotum finely and sparsely punctate; anteroventral margin of front femur with 3 , rarely 2 or 4 , large spines basally, posterior margin with a small distal spine.

Abdomen. Tergite 1 finely and sparsely punctate; T2-3 weakly punctate medially, strongly punctate laterally; T4-7 strongly punctate, posterior margin of T5 and 6 thickened laterally, laterocaudal angle of T7 produced into an acute laterally directed spine; supraanal plate strongly punctate, posterior margin entire, and laterocaudal angles weakly produced and broadly rounded; sternites weakly punctate medially, strongly punctate laterally, posterior margin of S7 shallowly concave exposing the subgenital plate, lateral margin produced anteriorly forming an obtuse angle often visible dorsally; subgenital plate finely punctate; cerci bulbous, densely setose ventrally, dorsal surface convex and setose, dorsal basal medial ridge weak or absent; genitalia reduced, L2d absent, L2vm present, L1 very weakly developed and only partially sclerotised, R2 ranging from a membranous cone with only the tip sclerotised, to a short weakly scerotised curved spur.

Female. Differs from male as follows: pronotum less developed, disc less depressed, anterior margin not thickened and not raised; posterior margin of sternite 7 entire; subgenital plate absent.

Measurements. Total length, $54.1-55.0$; pronotal length $\mathrm{x}$ width, $12.9-13.6 \times 20.6-22.3(\mathrm{n}=2)$.

Nymph. Similar to adults but without adult pronotal characters; colour, pale tan to brown for early instars, ferruginous to dark brown in later instars; abdominal punctations weaker, becoming stronger in later instars. 


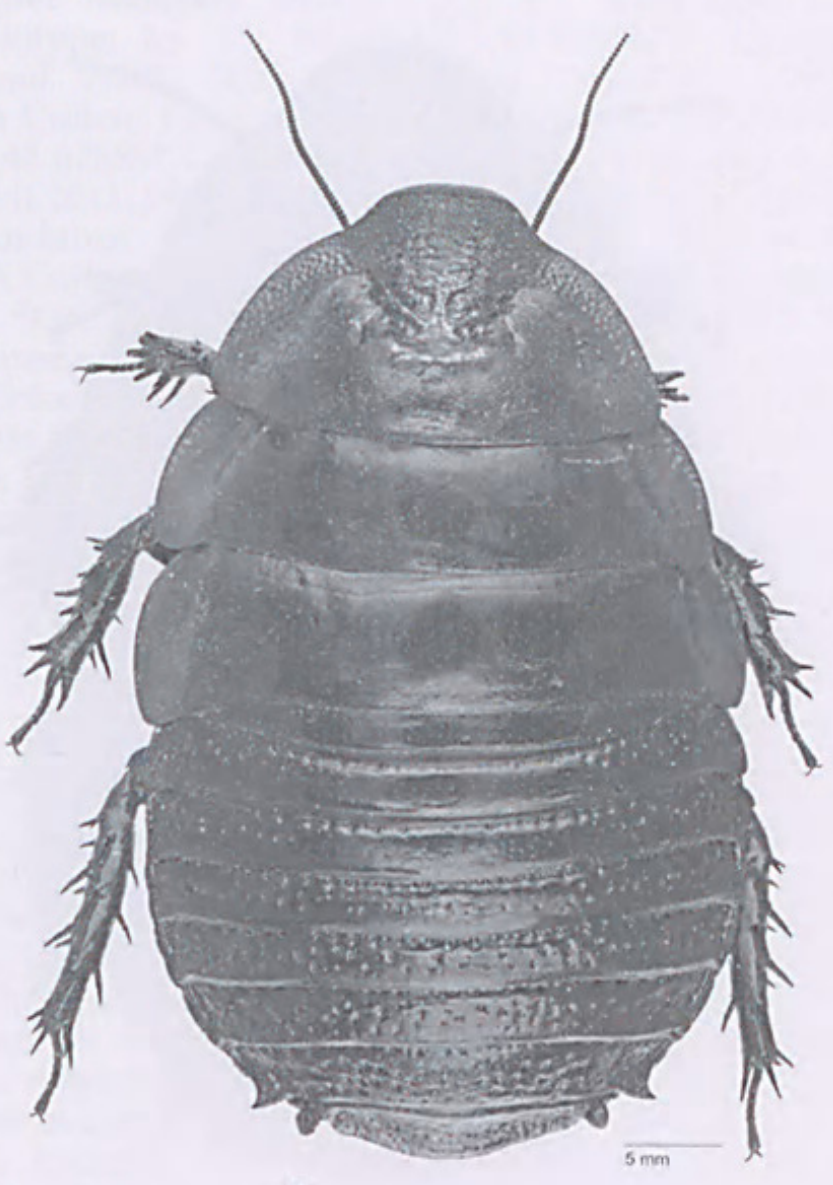

FIG. 1. Macropanesthia intermorpha sp. nov., paratype, QMT189901, dorsal view.

Distribution and remarks. This species is known only from areas within a few $\mathrm{km}$ north and south of Poison Creek on the Kennedy Development road, $101 \mathrm{~km}$ NNE of Hughenden. It is found in coarse sandy soil with diverse flora consisting mainly of eucalypts and Callitris. On the north eastern bank of Poison Creek adjacent to the road, $M$. intermorpha is sympatric with $M$. rhinoceros. The morphology of $M$. intermorpha superficially resembles certain features found within two genera. The thorax is similar to that of $M$. rhinoceros and $M$. heppleorum, including the absence of male pronotal tubercles in the latter, whilst its abdominal punctations resemble those of some northern populations of $G$. dilatatus.

\section{Macropanesthia lineopunctata sp. nov.} (Fig. 2)

Etymology. From a distinctive line of punctations on each tergite.
Material Examined. (Central Queensland)

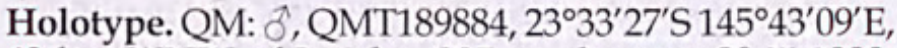
$42 \mathrm{~km}$ WNW of Jericho, $335 \mathrm{~m}$, dug up, 23.iii.1999, ACK, HAR, JRW.

Paratypes. ANIC: $10^{\prime}, 1$ 어, 'Busthinia' $23^{\circ} 33^{\prime} \mathrm{S} 145^{\circ} 43^{\prime} \mathrm{E}$, $45 \mathrm{~km}$ E of Barcaldine, dug up, 2.iv.1997, ACK, HAR, JRW. QM: 10, QMT189885, 1, QMT189886, same data as holotype; 10', QMT189887, 1․, QMT189888, $22^{\circ} 24^{\prime} 30^{\prime} \mathrm{S} 145^{\circ} 30^{\prime} 00^{\prime} \mathrm{E}, 68 \mathrm{~km}$ NE of Aramac, $320 \mathrm{~m}$, dug up, 14.iii.2006 HAR, JRW.

Other Material. JAWPC: 1 어 $33^{\prime}$ nymphs, $22^{\circ} 24^{\prime} 30^{\prime} \mathrm{S}$ $145^{\circ} 30^{\prime} 00^{\prime} \mathrm{E}, 68 \mathrm{~km}$ NE of Aramac, $320 \mathrm{~m}$, dug up, 14.iii.2006, HAR, JRW; $1 \delta^{\prime}, 10,1{ }^{\circ}$ nymph, $23^{\circ} 34^{\prime} 26^{\prime} \mathrm{S}$ $145^{\circ} 37^{\prime} 41^{\prime} \mathrm{E}, 51 \mathrm{~km}$ WNW of Jericho, dug up, 2.v.2000, HAR, JRW; $10^{\circ}$, 'Busthinia Station' $23^{\circ} 33^{\prime} \mathrm{S} 145^{\circ} 43^{\prime} \mathrm{E}$, $41.5 \mathrm{~km}$ WNW of Jericho, walking on ground surface, 12.xi.1998, JAW, JRW. QM: 23 nymphs, 30 nymphs, 'Busthinia' $23^{\circ} 33^{\prime} \mathrm{S} 145^{\circ} 43^{\prime} \mathrm{E}, 45 \mathrm{~km}$ E of Barcaldine, dug up, 2.iv.1997, ACK, HAR, JRW. USIC: 10', 1 , $23^{\circ} 00^{\prime} 02^{\prime} \mathrm{S} 145^{\circ} 43^{\prime} 36^{\prime} \mathrm{E}, 49 \mathrm{~km}$ ESE of Aramac, dug up, 15.iii.2006, HAR, JRW.

Description. Male. Colour. Head ferruginous, genae, clypeus, mandibles and labrum dark brown to black, maxillary and labial palps dark brown to black, antennae ferruginous, dark brown basally; pronotum ferruginous to dark brown; meso- and metanotum ferruginous; tergites and supraanal plate ferruginous to dark brown; legs ferruginous, coxae and femora ferruginous, dark brown apically, tibiae dark brown to black, tibial spines black, tarsi ferruginous; sternites ferruginous medially, dark brown to black laterally; supraanal plate dark brown to black; cerci ferruginous to brown; dorsal and ventral surfaces shiny.

Measurements. Total length, 58.2 (56.2 - 57.3); pronotal length $\times$ width, $16.1 \times 24.2(16.0-17.0$ $\times 22.8-23.0)(n=3)$.

Head. Hidden beneath pronotum, weakly and sparsely punctate, frons slightly depressed.

Thorax. Pronotum weakly punctate posteriorly and laterally, granulose anteriorly, disc depressed medially with two oblique anterior grooves, anterior margin thickened and raised medially; meso- and metanotum weakly and finely punctate; front femur with 2 or 3 , rarely 1 or 4 , large spines basally and a small spine distally on the anteroventral margin, posteroventral margin with a small distal spine. 
Abdomen. Tergite 1 weakly, finely and sparsely punctate; T2-6 weakly and finely punctate medially, with a few broad strong punctations laterally, anterior margin with a row of large deep anteriorly directed punctations (Fig. 2); T7 with fine weak punctations and a few broad weak punctations medially, strong broad punctations laterally, laterocaudal angle produced into a strong acute spine directed slightly dorsocaudally; supraanal plate with both strong broad punctations and weak fine punctations, laterocaudal angles produced into blunt obtuse spines, posterior margin usually with ventrally directed crenulation medially; sternites finely and weakly punctate medially, strongly and broadly punctate laterally, posterior margin of S7 shallowly concave exposing subgenital plate; subgenital plate finely and weakly punctate; cerci bulbous and densely setose; genitalia reduced and variable, L2d absent, L2vm present, L1 ranging from weakly developed and very weakly sclerotised to absent, R2 weakly sclerotised and ranging from a small curved spine to a small hook.

Female. Differs from male as follows: pronotum less developed, disc less depressed, anterior margin not thickened and raised; posterior margin of sternite 7 entire; subgenital plate absent.

Measurements. Total length, 55.0 - 55.5; pronotal length $\times$ width, $14.1-14.2 \times 22.1-22.5$ $(n=3)$.

Nymph. Similar to adults but without adult pronotal characters; colour, pale tan to brown for early instars, ferruginous to dark brown in later instars; abdominal punctations weaker, becoming stronger in later instars.

Distribution and Remarks. Initially, $M$. lineopunctata was known only from a dense population at its type locality in central Queensland. Further collections have shown it to be widespread to the north and west of this collection site. It is found mostly in coarse sandy soil. The flora consists of a diverse savannah woodland with eucalypts and Callitris being dominant.

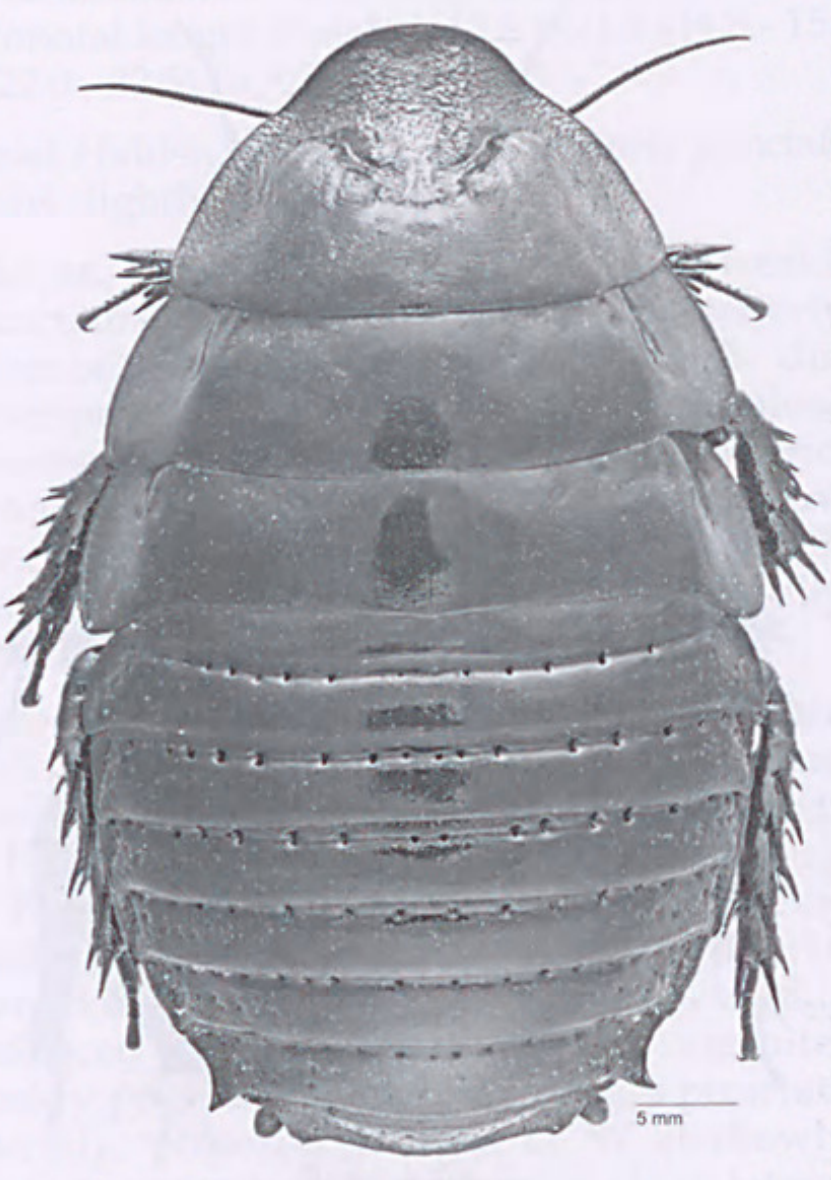

FIG. 2. Macropanesthia lineopunctata sp. nov., holotype, dorsal view.

\section{Macropanesthia mutica sp. nov.} (Figs 3-5)

Etymology. From muticus, alluding to the lack of processes where such usually occur. All other Geoscapheinae possess spines on tergites 6 and or 7 .

Material Examined. (North East Queensland)

Holotype. QM: đ., QMT189893, 1701'14'S 145³6'00'E, $19 \mathrm{~km}$ ESE of Mareeba, $765 \mathrm{~m}$, dug up, 29.ix.1992 HAR, JAW.

Paratypes. ANIC: $1 \delta^{2}, 1$, same data as holotype. QM: 10, QMT189894, 1, QMT189895, same data at holotype; 10े, QMT189896, 1ㅇ, QMT189897, $17^{\circ} 06^{\prime} 05^{\prime} \mathrm{S} 145^{\circ} 33^{\prime} 01^{\prime} \mathrm{E}, 8.8 \mathrm{~km} \mathrm{~W}$ of Mount Edith, $890 \mathrm{~m}$, dug up, 13.vi.2011 J.A.Cullen, JAW; 13, QMT189898, $16^{\circ} 57^{\prime} 08^{\prime} \mathrm{S} 145^{\circ} 35^{\prime} 53^{\prime} \mathrm{E}, 19 \mathrm{~km}$ ENE of Mareeba, $640 \mathrm{~m}$, dug up, 16.ii.2002 J.A.Cullen, HAR, JAW; 1 , QMT189899, 16 ${ }^{\circ} 57^{\prime} 08^{\prime} \mathrm{S} 145^{\circ} 35^{\prime} 53^{\prime} \mathrm{E}, 19$ $\mathrm{km}$ ENE of Mareeba, $640 \mathrm{~m}$, dug up, 18.xi.2006 J.A.Cullen, HAR, JAW, JRW. 
Other Material. JAWPC: $1 \hat{\delta}, 2 \circ$, same data as holotype; $1 \delta, 1$,, S17.01577 ${ }^{\circ}$ E145.61620 , Lambs Head Track, 1023 m, dug up, 3.vii.2011, JAW,

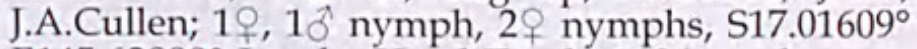
E145.62889 $9^{\circ}$ Lambs Head Track, 1186 m, dug up, 3.vii.2011, JAW, J.A.Cullen; $1{ }^{\circ}$, S17.027 $^{\circ}$ E145.606 ${ }^{\circ}$, Pandanus Creek, $695 \mathrm{~m}$, dug up, 16.ii.2002, J.A.Cullen, HAR, JAW. DAFF, Brisbane: $1 \delta$, Clohesy R. State Forest Reserve, on ground, 10.iv.1972, S. Dansey, J.H.B; $2 \hat{\jmath}$, Upper Clohesy R, in soil under rainforest 18.iv.1975, J.H.Barrett; QM: 28,2 , same data as holotype; 19, Lambs Head Track, via Davies Ck Road, 10.xii.1989, 800-900 m, GBM, Thompson, Janetzki; $1 \delta$, S17.027 E145.606 , Pandanus Creek,

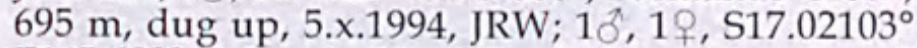
E145.60834 $4^{\circ}$, Lambs Head Track, $846 \mathrm{~m}$, on ground surface, viii 2003, JAW, J.A.Cullen, N.J.Cullen, K.L.Anderson, R.Anderson; 3 , $2{ }^{\lambda}$ nymphs, 5 क

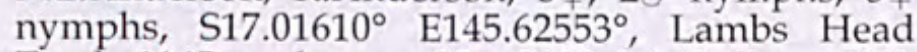
Track, 1145 m, dug up, 31.v.2009, J.A.Cullen, JAW; $10^{\circ}, \mathrm{S} 17.027^{\circ} \mathrm{E} 145.606^{\circ}$, Pandanus Creek, $695 \mathrm{~m}$, dug up, 9.xi.1994, HAR, JRW; $10^{\circ}$, S17.03786 E145.57837º, Mount Turtle, 915 m, dug up, 29.iii.2009, D.Foreman,

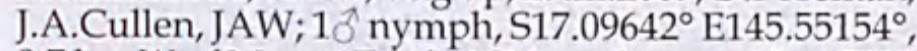
$8.7 \mathrm{~km} \mathrm{~W}$ of Mount Edith, $1015 \mathrm{~m}$, dug up, 13.vi.2011 J.A.Cullen, JAW. USIC: 10,1 , 10,1 nymph, 1 우 nymph, same data as holotype; 2 , 50 nymphs, $2{ }^{\circ}$ nymphs, $\mathrm{S} 16.9521^{\circ} \mathrm{E} 145.5982^{\circ}$, Clohesy River, $640 \mathrm{~m}$ dug up, 16.ii.2002 J.A.Cullen, HAR, JAW; 23 , 2 nymphs, $16^{\circ} 57^{\prime} 08^{\prime} \mathrm{S} 145^{\circ} 35^{\prime} 53^{\prime} \mathrm{E}, 19 \mathrm{~km}$ ENE of Mareeba, 640 m, dug up, 18.xi.2006 J.A.Cullen, HAR, JAW, JRW.

Description. Male. Colour. Head ferruginous, clypeus light tan to orange, mandibles dark brown to black; pronotum ferruginous to dark brown, anterior margin dark brown to black medially, disc dark brown to black posteriorly; meso- and metanotum ferruginous to dark brown; legs ferruginous, tibial spines dark brown to black apically; tergites 1-6 ferruginous to dark brown, often darker laterally; T7 and supraanal plate dark brown to black; cerci dark brown to black; sternite 2 dark brown to black laterally; S3-6 ferruginous medially, dark brown to black laterally; S7 dark brown to black, ferruginous anteromedially; subgenital plate dark brown to black; dorsal surface matt, ventral surface somewhat shiny.

Measurements. Total length, 57.2 (56.4 - 58.0); pronotal length $\times$ width, $17.5 \times 26.9(16.3-17.1$ $\times 24.9-25.4)(n=4)$.

Head. Hidden by pronotum, slightly depressed above clypeus, finely and weakly punctate.
Thorax. Pronotum convex, punctate laterally with weak punctations posterolaterally, anterior margin thickened and raised medially forming two partly fused blunt tubercles (Fig. 4), weakly striate $3-4 \mathrm{~mm}$ posterior to marginal tubercles, disc widely depressed from 4-5 $\mathrm{mm}$ from marginal tubercles to $2-3 \mathrm{~mm}$ from posterior margin, and thickened medially, depressed disc floor weakly roughened, anterior portion of disc with a pair of oblique posteriorly curved grooves, terminating 2-3 $\mathrm{mm}$ from anterolateral margin; mesoand metanotum sparsely and very weakly punctate, having fine irregular grooves; anteroventral margin of front femur with 2 or 3 , rarely 1 or 4 , large spines basally, a very small spine distally, and posterior margin with a large distal spine.

Abdomen. Tergites 1-6 weakly and sparsely punctate medially, with punctations becoming stronger and denser laterally; posterior margin of T6 slightly thickened laterally forming a weakly crenulate ridge; T7 with large shallow punctations, and the laterocaudal angle produced into a small rounded spine directed laterocaudally to slightly ventrocaudally; supraanal plate with large punctations, convex posteriorly, posterior margin entire, and laterocaudal angles weakly produced and broadly rounded; sternite 2 densely punctate laterally; S3-6 very weakly and sparsely punctate medially and densely punctate laterally; S7 very weakly and sparsely punctate anteromedially, weakly punctate laterally and posteriorly, posterior margin concavely truncated exposing subgenital plate, and lateral margin produced anteriorly, forming an obtuse angle visible dorsally (Fig. 5); subgenital plate weakly punctate; cerci broadly triangular, tapering to a broadly rounded tip, dorsal surface weakly punctate and sparsely setose apically and with a smooth medial ridge basally, ventral surface densely setose; genitalia reduced, L2d absent, L2vm present, L1 present but not strongly sclerotised, $\mathrm{R} 2$ ranging from a curved sclerotised spur to a weakly curved sclerotised hook.

Female. Differs from male as follows: pronotum less developed, disc less depressed, posterior margin not thickened, anterior margin only 

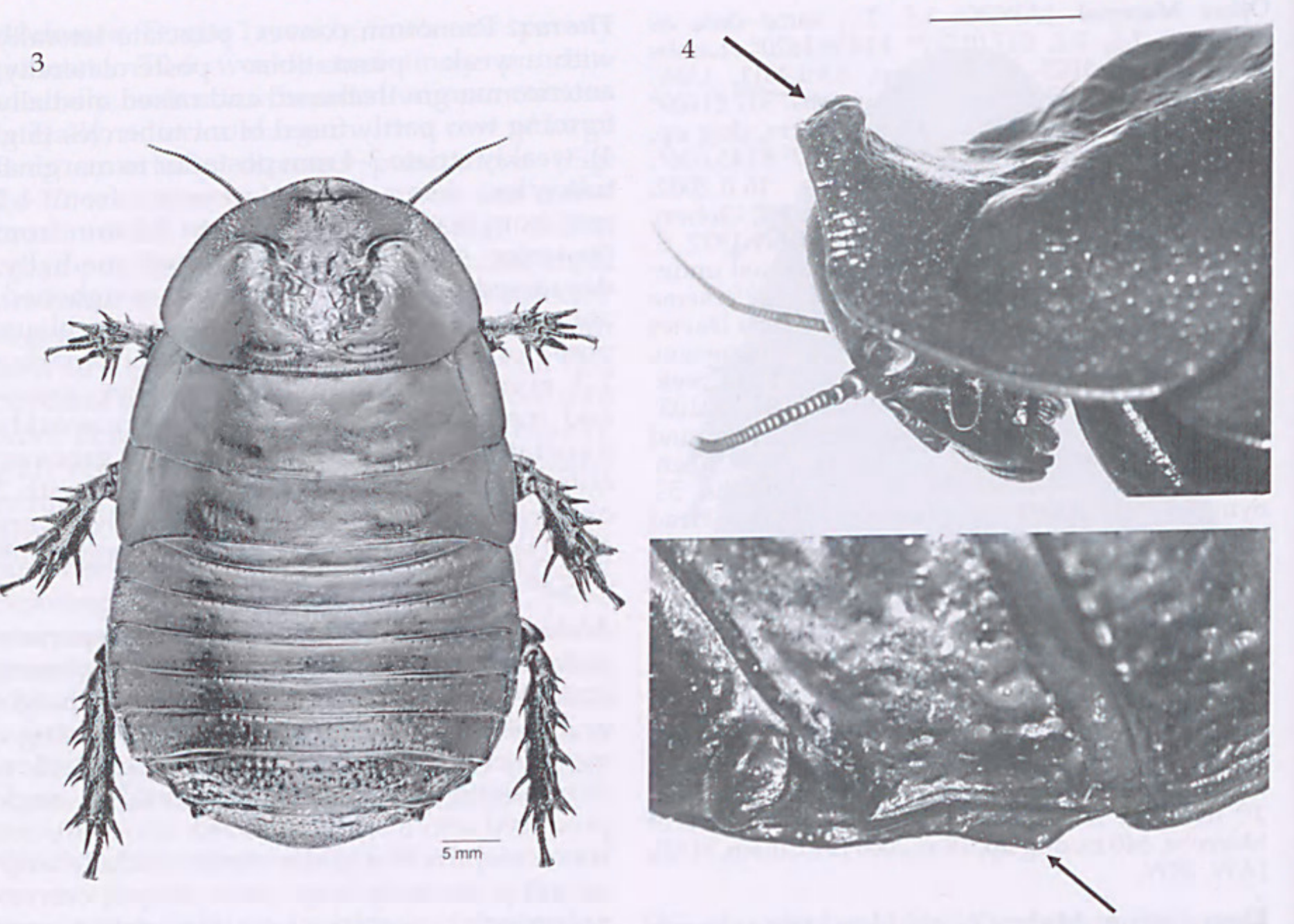

FIGS 3-5. Macropanesthia mutica sp. nov., holotype: 3 , dorsal view; 4, pronotum, lateral view; 5 , lateral margin of sternite 7.

slightly thickened and without tubercles; posterior margin of S7 entire; subgenital plate absent; abdomen relatively wider than male giving a pear shaped outline.

Measurements. Total length, 52.9 - 59.2; pronotal length $\times$ width, $15.0-16.1 \times 23.0-25.4(n=4)$.

Nymph. Similar to adults but without adult pronotal characters; colour, pale tan to brown for early instars, ferruginous to dark brown in later instars; abdominal punctations weaker, becoming stronger in later instars.

Distribution and Remarks. Known from the northern and western flanks of the Lamb Range in north Queensland, from near Clohesy River to near to Lake Tinaroo. Sites are semi-open eucalypt and sheoak forests, and at Pandanus Creek, rainforest. Ground surface specimens were first collected by foresters working in Clohesy State Forest in the 1970s and the authors have since dug up specimens close to these original collection sites. A specimen has also been collected by JAW close to the summit of Lambs Head. This species does not fit any of the original generic descriptions for soil burrowing cockroaches (Roth 1977; Walker et al.1994), however it clearly belongs within the subfamily Geoscapheinae. In the opinion of the authors, the existing genera may not reflect phylogeny, and thus at this present time the erection of a new genus to accommodate $M$. 
mutica would not be appropriate. Accordingly, the current key to the genera of Geoscapheinae (Walker et al., 1994) has been altered by deleting the reference to the laterocaudoangle of $\mathrm{T} 7$, and this species keys to Macropanesthia.

\section{Macropanesthia spuritegmina sp. nov.} (Fig. 6)

Etymology. Reference to the coloured lateral patches on meso- and metanota; from a short distance away, these patches superficially resemble tegmina.

Material Examined. (Central Queensland)

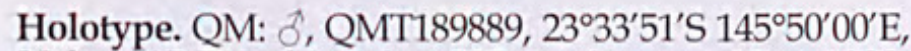
$30 \mathrm{~km} \mathrm{WNW}$ of Jericho, $335 \mathrm{~m}$, dug up, 12.xi.1998, JAW, JRW.

Paratypes. ANIC: 1 , same data as holotype; $10^{\circ}$, $23^{\circ} 33^{\prime} 53^{\prime} \mathrm{S} 145^{\circ} 48^{\prime} 39^{\prime} \mathrm{E}, 32 \mathrm{~km}$ WNW of Jericho, dug up, 23,iii.1999, ACK, HAR, JRW. QM:123, QMT189890, 1., QMT189891, same data as holotype; 1, QMT189892, 23⒊ $34^{\prime} 03^{\prime} \mathrm{S} 145^{\circ} 51^{\prime} 49^{\prime} \mathrm{E}, 27 \mathrm{~km}$ WNW of Jericho, 335 m, dug up, 21.v.2008 HAR, JAW.

Other Material. JAWPC: 19,16 nymph, same data as holotype; $2 \circ, 3$ nymphs, $23^{\circ} 33^{\prime} 52^{\prime} \mathrm{S} 145^{\circ} 48^{\prime} 42^{\prime} \mathrm{E}$, $32 \mathrm{~km}$ WNW of Jericho, dug up, 22.iii.2004, HAR, JRW; $10^{\prime} 23^{\circ} 34^{\prime} 03^{\prime} \mathrm{S} 145^{\circ} 51^{\circ} 49^{\prime} \mathrm{E}, 27 \mathrm{~km}$ WNW of Jericho, $335 \mathrm{~m}$, dug up, 21.v.2008, HAR, JAW. USIC: $20^{\circ}, 10^{\circ}$ nymph, $30^{\circ}$ nymphs, $\mathrm{S} 23.5675^{\circ} \mathrm{E} 145.8636^{\circ}, 27$ $\mathrm{km}$ WNW of Jericho, dug up, 17.ix.2012, HAR, JRW.

Description. Male. Colour. Head black, clypeus dark brown with a pale brown medial band and often pale brown laterally, antennae black, mandibles black basally and distally but brown medially; pronotum black; mesoand metanotum black, submarginal smoky yellowish to orange patches anterolaterally extending nearly to laterocaudal angles (Fig. 6), anterolateral patch larger on mesonotum than metanotum; tergite 1 black; T2-7 ferruginous to dark red brown anteromarginally, black posteromarginally and laterally; supraanal plate dark red brown to black; legs black; sternites dark red brown anteriorly tending to black posteriorly; subgenital plate black; cerci black; dorsal and ventral surfaces shiny.

Measurements. Total length, 39.4 (36.8 - 37.1); pronotal length $\times$ width, $10.6 \times 17.2(10.0 \times 15.0$ -15.2) $(\mathrm{n}=2)$.

Head. Finely punctate, hidden beneath pronotum.
Thorax. Pronotum broadly and weakly punctate lateromarginally, finely punctate posteromedially, anterior margin thickened and raised medially, disc depressed and granular to anterior margin and with two weak oblique anterior grooves; meso- and metanotum finely and sparsely punctate; anteroventral margin of front femur with 2 or 3 , rarely 4 , large spines basally, posterior margin with a large distal spine.

Abdomen. Tergite 1 smooth; T2-7 finely and sparsely punctate with punctations becoming dense and stronger laterally; laterocaudal angle of T7 produced into a small acute spine directed ventrocaudally; supraanal plate coarsely and weakly punctate, posterior margin with ventrally directed small acute crenulations medially, laterocaudal angles weakly developed; sternites weakly punctate medially, densely and weakly punctate laterálly; posterior margin of S7 weakly concave exposing subgenital plate; subgenital plate weakly punctate; cerci acutely triangular, tapering to a finely rounded point, densely setose ventrally, dorsal surface glabrous and with a weak rounded ridge basally; genitalia much reduced, L2vm present, L2d, L1 and R2 absent.

Female. Differs from male as follows: pronotum less developed, disc less depressed, posterior margin not thickened, anterior margin not thickened and not raised; posterior margin of sternite 7 entire; subgenital plate absent; generally larger and wider.

Measurements. Total length, 36.4 - 42.3; pronotal length $\times$ width, $10.3-10.9 \times 17.1-18.7(n=3)$.

Nymph. Similar to adults but without adult pronotal characters; colour, smoky dark brown; abdominal punctations weaker, becoming stronger in later instars; smoky yellowish to orange patches on meso- and metanota not as defined as in adults.

Distribution and Remarks. Known only from a localised area adjoining the Capricorn Highway, east of Alice River for $6 \mathrm{~km}$, in sandy soil where Callitris dominates. Despite extensive efforts, no further populations have been found. Some specimens have pronota with weak smoky yellowish to orange patches posterolaterally. 


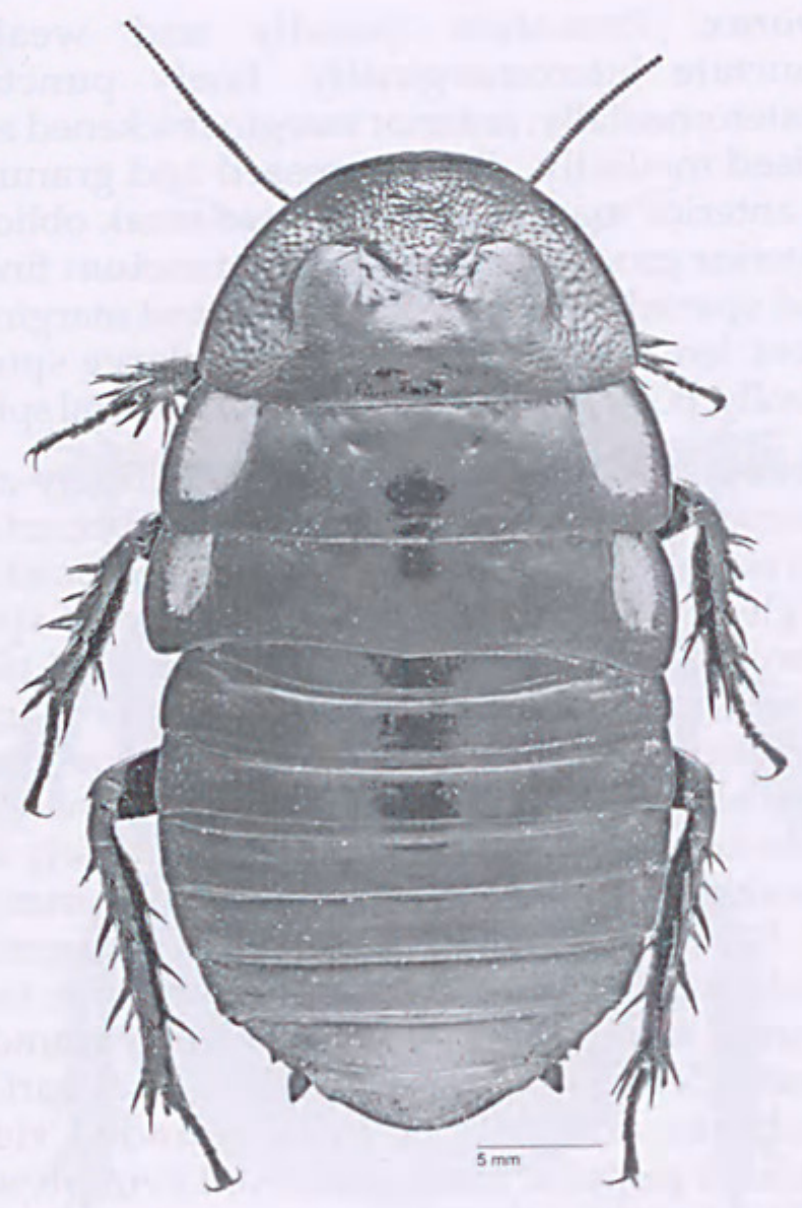

FIG. 6. Macropanesthia spuritegmina sp. nov., holotype, dorsal view.

\section{Neogeoscapheus hanni sp. nov.} (Figs 7-9)

Etymology. After the Hann Tableland, where it was first discovered.

\section{Material Examined. (North East Queensland)}

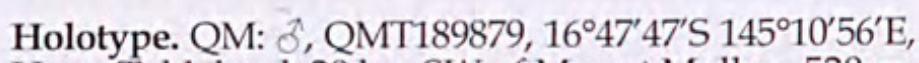
Hann Tableland, $20 \mathrm{~km}$ SW of Mount Molloy, $520 \mathrm{~m}$, dug up, 10.ii.1996, GBM, HAR, JAW, JRW.

Paratypes. ANIC: $1 \hat{0}, 1$, same data as holotype. QM: 19, QMT189880, same data as holotype; 10 , QMT189881, $16^{\circ} 48^{\prime} \mathrm{S} 145^{\circ} 10^{\prime} \mathrm{E}$, Hann Tableland, 20 $\mathrm{km}$ SW of Mount Molloy, dug up, 8.xii.1995, GBM; 10े, QMT189882, $16^{\circ} 39^{\prime} 10^{\prime} \mathrm{S} 145^{\circ} 15^{\prime} 36^{\prime} \mathrm{E}, 8 \mathrm{~km}$ WNW of Mount Molloy, $500 \mathrm{~m}$, dug up, 14.xii.2003, J.A.Cullen, JAW; 10 ', QMT189883, 16 $57^{\prime} 14^{\prime}$ S $145^{\circ} 13^{\prime} 54^{\prime} \mathrm{E}$, 'Glen Russell', $22 \mathrm{~km}$ WNW of Mareeba, $575 \mathrm{~m}$, dug up, 17.ii.2002, J.A.Cullen, GBM, HAR, JAW.

Other Material. JAWPC: 5 ,, $1 \delta^{\prime}$ nymph, $16^{\circ} 57^{\prime} 14^{\prime} \mathrm{S}$ $145^{\circ} 13^{\prime} 54^{\prime} \mathrm{E}$, 'Glen Russell', $22 \mathrm{~km}$ WNW of Mareeba, $575 \mathrm{~m}$, dug up, 17.ii.2002, J.A.Cullen, GBM, HAR, JAW; $10^{\circ}, \mathrm{S} 16.6527^{\circ} \mathrm{E} 145.2601^{\circ}$, Bowerbird Ck, $8 \mathrm{~km}$ WNW of
Mt Molloy, 495 m, dug up, 17.x.2006, N.Lo, JAW; 10 , $20,53^{2}$ nymphs, 1 i nymph, $516.6527^{\circ} \mathrm{E} 145.2601^{\circ}$, Bowerbird Ck, $8 \mathrm{~km}$ WNW of Mt Molloy, $495 \mathrm{~m}$, dug up, 4.v.2008, J.A.Cullen, JAW; $10 \hat{0}, 2$ ㅇ, 50 nymphs, 3 웅 nymphs, S16.6642 ${ }^{\circ}$ E145.2995, $3.5 \mathrm{~km}$ WNW of Mt Molloy, $425 \mathrm{~m}$, dug up, 26.iii.2004, HAR, JAW, JRW; 1 , 2 , nymphs, S16.6648 E145.2989 ${ }^{\circ}$, Sandy Creek, NW of Mt Molloy, 445 m, dug up, 24.x.2010, JAW. DAFF, Brisbane: $1 \delta$, Hann Tableland via Mt Molloy, 14.xii.1995 GBM; 10, $\mathrm{N}$ base of Hann Tableland, $500 \mathrm{~m}, 10 . \mathrm{ii} .1996, \mathrm{GBM} . \mathrm{QM}: 1 \hat{\gamma}, 20,1 \hat{\mathrm{n}}$ nymph, 1 nymph, same data as holotype; 10,10 nymph, S16.63885 $5^{\circ}$ E145.24513 ${ }^{\circ}$, Luster Ck, $9.5 \mathrm{~km}$ WNW of Mt Molloy, $425 \mathrm{~m}$, dug up, 9.viii.2009, J.A.Cullen, JAW; 1 ㅇ, $\mathrm{S} 16.63455^{\circ} \mathrm{E} 145.24861^{\circ}$, Luster Ck, 9.5 $\mathrm{km}$ WNW of Mt Molloy, $505 \mathrm{~m}$, dug up, 9.viii.2009, J.A.Cullen, JAW; 10,2 , 3 o nymphs, $16^{\circ} 39^{\prime} 10^{\prime}$ ' $145^{\circ} 15^{\prime} 36^{\prime} \mathrm{E}, 8 \mathrm{~km}$ WNW of Mount Molloy, $500 \mathrm{~m}$, dug up, 14.xii.2003, J.A.Cullen, JAW; 1 \%, S16.6551 $\mathrm{E} 145.2950^{\circ}, 4.4 \mathrm{~km}$ NW of Mt Molloy, $584 \mathrm{~m}$, dug up, 2.vii.2008, JAW. USIC: $20^{2}, 1$, 10 nymph, $16^{\circ} 56^{\circ} 56^{\circ} \mathrm{S}$ $145^{\circ} 13^{\prime} 25^{\prime} \mathrm{E}$, 'Glen Russell', Hann Tableland, $33 \mathrm{~km}$ SSW of Mount Molloy, $580 \mathrm{~m}$, dug up, 25.xi.2008 HAR, JRW; 1 , 1 i nymph, S16.6527 $7^{\circ}$ E145.2601 , Bowerbird Ck, $8 \mathrm{~km}$ WNW of Mt Molloy, $495 \mathrm{~m}$, dug up, 26.iii.2004, HAR, JAW, JRW; 10 , 1 nymph, $\mathrm{S} 16.6590^{\circ} \mathrm{E} 145.2630^{\circ}, 7.5 \mathrm{~km}$ WNW of Mt Molloy, $520 \mathrm{~m}$, dug up, 26.iii.2004 HAR, JAW, JRW; 1 ', S16.6642 ${ }^{\circ}$ E145.2995, $3.5 \mathrm{~km}$ WNW of Mt Molloy, $425 \mathrm{~m}$, dug up, 10.v.2003, JAW; $10^{\circ}, 1$ ㅇ, S16.6642 E145.2995, $3.5 \mathrm{~km}$ WNW of Mt Molloy, $425 \mathrm{~m}$, dug up, 21.xi.2008, HAR, JAW.

Description. Male. Colour. Head ferruginous, clypeus often paler, genae and basal half of labrum dark brown to black; thoracic nota ferruginous, usually paler laterally, dark brown to black medially; legs ferruginous, tibial spines and tarsi dark brown to black; abdominal tergites ferruginous anteriorly, dark brown to black posteriorly; supraanal plate dark brown to black; sternite 2-6 ferruginous medially, dark brown to black laterally; subgenital plate ferruginous, lateral and posterior margins dark brown to black; cerci ferruginous to dark brown; dorsal surface matt, ventral surface somewhat shiny.

Measurements. Total length, 64.9 (60.1 - 61.9); pronotal length $\times$ width, $18.6 \times 28.1(17.0-17.8$ $\times 25.4-28.0)(n=4)$.

Head. Hidden beneath pronotum, finely and weakly punctate, frons weakly striate.

Thorax. Pronotum convex, finely punctate laterally, anterior margin raised medially with two slightly recurved submarginally fused tubercles, disc weakly striate posterior to 

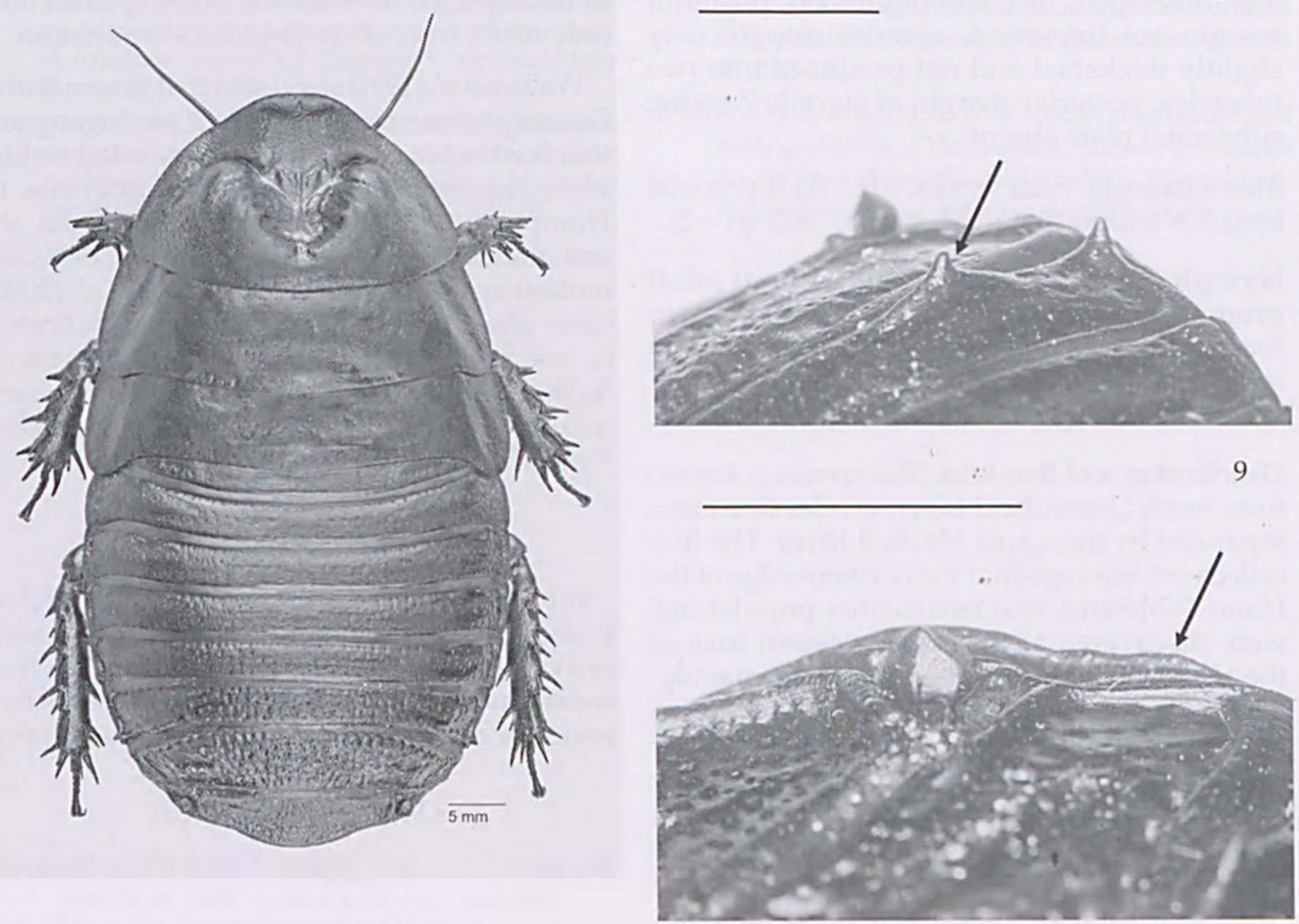

FIGS 7-9. Neogeoscapheus hanni sp. nov., holotype: 7, dorsal view; 8, tergite 6, dorsal view; 9; lateral margin of sternite 7 .

submarginal tubercles, depressed medially with a median groove and two oblique anterior grooves, lateral margins raised forming four broad rounded tubercles; meso- and metanotum finely and weakly punctate, with weak tegminal depressions, fine irregular sculpturing medially; anteroventral margin of front femur with 2 to 4 , usually 3 , large spines basally, posterior margin with a large distal spine.

Abdomen. Tergites 1-6 finely punctate with punctations stronger laterally; T6 with pronounced punctations medially, the laterocaudal angle produced into an acute laterodorsally directed spine, posterior margin with a similar acute spine 4-6 $\mathrm{mm}$ from the lateral margin (Fig. 8); T7 strongly punctate, the anterior margin with a row of strong submarginal punctations, the posterior margin thickened where it meets a very weakly developed laterocaudal angle; supraanal plate strongly and coarsely punctate, lateral and posterior margins thickened and finely punctate; sternites smooth and shiny medially, weakly and densely punctate posterolaterally; S7 smooth anteromedially, weakly punctate marginally, lateral margins produced beyond T7 and visible dorsally (Fig. 9), the posterior margin concavely truncated exposing a finely punctate subgenital plate; cerci broadly triangular, tapering to a broadly rounded apex, dorsal surface glabrous and concave either side of a rounded basal median ridge; genitalia reduced, L2d absent, L2vm present, L1 present but weakly developed and not strongly sclerotised, R2 a well sclerotised curved spine. 
Female. Differs from male as follows: pronotum less developed, disc less depressed, posterior margin not thickened, anterior margin only slightly thickened and not produced into two tubercles; posterior margin of sternite 7 entire; subgenital plate absent.

Measurements. Total length, 60.8 - 63.6; pronotal length $\times$ width, $16.2-17.0 \times 24.8-26.1(n=2)$.

Nymph. Similar to adults but without adult pronotal characters; colour, pale tan to brown for early instars, ferruginous to dark brown in later instars; abdominal punctations weaker, becoming stronger in later instars.

Distribution and Remarks. This species is known from north Queensland from two elevated areas separated by the upper Mitchell River. The first collections were made at the northern edge of the Hann Tableland, and two further populations were discovered at the south western base of the tableland on 'Glen Russell'. Subsequently, a number of smaller populations have also been discovered on the western slopes of the Carbine Tableland. All sites have sandy granitic soils with eucalypt dominated vegetation. Specimens from the Carbine Tableland exhibit considerable variation in the development of spines on the posterior margin of T6. Some specimens possess a single spine on each side whilst others have two or three and of varying size. This is in contrast with populations to the west, associated with the Hann Tableland, where all specimens possess only single spines. The other three species of Neogeoscapheus found in central and south east Queensland are considerably smaller than N. hanni.

\section{DISCUSSION}

The Geoscapheinae is a well defined group with regard to their biology. All 24 species are found in Queensland, with five also occurring in other states. While most species have fairly limited ranges, five are widely distributed (M. rhinoceros, $M$. heppleorum, $M$. kraussiana, G. dilatatus, G. robustus); the latter three species are found west of the Great Dividing Range. Some species occur as sympatric populations. We believe that discovery of further new species of geoscapheines unlikely, although recognition of new species from within existing collections may result from more detailed examination.

Walker et al. (1994) suggested that genera within Geoscapheinae may not reflect phylogeny and that further studies of intergeneric relationships were required. Later studies on isozymes by Humphrey et al. (1998), on male genitalia and oothecal membranes, Walker and Rose (1998), and molecular techniques by Maekawa et al. (2003), have also suggested the generic classification is not well supported. We are undertaking further studies to clarify and review phylogenetic relationships within and between Australian Panesthiinae and Geoscapheinae.

\section{ACKNOWLEDGEMENTS}

We appreciate the valuable assistance of A.C. Kotze and G.B. Monteith. Habitus images were provided by Geoff Thompson and for which we are most grateful. Insightful comments by a reviewer of the manuscript were very helpful.

\section{LITERATURE CITED}

Beccaloni, G. W. \& Eggleton, P. 2011. Order Blattodea Brunner von Wattenwyl, 1882. In Zhang, Z.-Q. (ed.). Animal biodiversity: an outline of higherlevel classification and survey of taxonomic richness. Zootaxa 3148: 199-200.

2013. Order Blattodea. Zootaxa 3703: 46-48.

Humphrey, M., Colgan, D.J. \& Rose, H.A. 1998. Electrophoretic studies of cockroaches of the Australian endemic subfamily Geoscapheinae. Zoological Journal of the Linnean Society 124: $209-$ 234.

Inward, D., Beccaloni, G.W. \& Eggleton, P. 2007. Death of an order: a comprehensive molecular phylogenetic study confirms that termites are eusocial cockroaches. Biology Letters 3: 331-335.

Maekawa, K., Lo, N., Rose, H.A. \& Matsumoto, T. 2003. The evolution of soil-burrowing cockroaches (Blattaria: Blaberidae) from wood-burrowing ancestors following an invasion of the latter from Asia into Australia. Proceedings of the Royal Society London B 270: 1301-1307.

McKittrick, F.A. 1964. Evolutionary studies of cockroaches. Cornell University Agricultural Experiment Station Memoirs 389: 1-197. 
Roth, L.M. 1977. A taxonomic revision of the Panesthiinae of the world. I. The Panesthiinae of Australia (Dictyoptera: Blattaria: Blaberidae). Australian Journal of Zoology Supplementary Series 48: 1-112.

Rugg, D. \& Rose, H.A. 1984. The taxonomic significance of reproductive behaviour in some Australian cockroaches (Blattodea: Blaberidae). Journal of the Australian Entomological Society 23:118.
Walker, J.A., Rugg, D. \& Rose, H.A. 1994. Nine new species of Geoscapheinae (Blattodea: Blaberidae) from Australia. Memoirs of the Queensland Museum 35: 263-284.

Walker, J.A. \& Rose, H.A. 1998. Oothecal structure and male genitalia of the Geoscapheinae and some Australian Panesthia (Blattodea: Blaberidae). Australian Journal of Entomology 37: 23-26. 


\section{$2 \mathrm{BHL}$ Biodiversity Heritage Library}

Rose, H A, Walker, J. A., and Woodward, J R. 2014. "Five new species of soil burrowing cockroaches from Queensland (Blattodea: Blaberidae:

Geoscapheinae)." Memoirs of the Queensland Museum 59, 11-23. https://doi.org/10.17082/j.2204-1478.59.2014.2014-02.

View This Item Online: https://www.biodiversitylibrary.org/item/282460

DOI: https://doi.org/10.17082/j.2204-1478.59.2014.2014-02

Permalink: https://www.biodiversitylibrary.org/partpdf/306749

\section{Holding Institution}

Queensland Museum

\section{Sponsored by}

Atlas of Living Australia

\section{Copyright \& Reuse}

Copyright Status: In copyright. Digitized with the permission of the rights holder.

Rights Holder: Queensland Museum

License: http://creativecommons.org/licenses/by-nc-sa/4.0/

Rights: http://biodiversitylibrary.org/permissions

This document was created from content at the Biodiversity Heritage Library, the world's largest open access digital library for biodiversity literature and archives. Visit BHL at https://www.biodiversitylibrary.org. 